\title{
Pengaruh Mutagen Kimia EMS (Ethyl Methane Sulphonate) Terhadap Daya Berkecambah Benih Tanaman Tembakau var. Marakot
}

\author{
Bangun Surya Putra dan Kristanti Indah Purwani \\ Departemen Biologi, Fakultas Ilmu Alam, Institut Teknologi Sepuluh Nopember (ITS) \\ Jl. Arief Rahman Hakim, Surabaya 60111 Indonesia \\ e-mail:kristanti@bio.its.ac.id
}

\begin{abstract}
Abstrak-Penyediaan benih bermutu merupakan permasalahan dalam peningkatan produksi tembakau. Induksi mutasi merupakan salah satu cara untuk mendapatkan varietas unggul yang memiliki produktivitas tinggi dan kualitas yang baik. Beberapa penelitian mengenai penggunaan mutagen kimia EMS (Ethyl Methane Sulphonate) menunjukkan pengaruh terhadap perkecambahan benih tanaman sehingga diperlukan penelitian untuk mengetahui pengaruh konsentrasi mutagen EMS terhadap daya berkecambah benih tanaman tembakau. Beberapa variasi konsentrasi EMS yang digunakan pada penelitian ini yaitu $0,1 \%, 0,5 \%, 1 \%$, dan $1,5 \%$. Hasil penelitian menunjukkan bahwa perbedaan konsentrasi mutagen EMS berpengaruh nyata terhadap daya berkecambah benih tembakau. Perlakuan EMS dengan konsentrasi 1\% dan 1,5\% menunjukkan penurunan daya kecambah benih.
\end{abstract}

Kata Kunci- Benih tembakau, Daya kecambah, Induksi mutasi, Mutagen EMS .

\section{PENDAHULUAN}

$\mathrm{T}$ ANAMAN tembakau (Nicotiana tabacum) merupakan salah satu komoditi perdagangan yang mampu menghasilkan cukai terbesar, menghasilkan devisa dan menyerap tenaga kerja yang relatif besar untuk aktivitas produksi dan pemasarannya. Tembakau memberikan pendapatan negara dari cukai rata-rata 43 trilyun/tahun [1]. Indonesia juga merupakan salah satu dari sepuluh besar negara produsen daun tembakau, yang memberikan kontribusi sekitar 2,3\% suplai dunia [2]. Pentingnya peran tembakau terhadap perekonomian negara menyebabkan kebutuhan produksi tembakau semakin meningkat. Peningkatan produksi tembakau perlu diimbangi dengan peningkatan kualitas tanaman tembakau sehingga tembakau produksi lokal dapat laku di pasar dalam negeri maupun luar negeri. Untuk mendukung perekonomian negara melalui perdagangan dan ekspor tembakau, maka diperlukan varietas unggul yang memiliki produktivitas tinggi dan kualitas yang baik.

Penggunaan benih bermutu dari varietas unggul sangat menentukan keberhasilan peningkatan produksi tanaman [3]. Permasalahan yang dihadapi dalam pengembangan tembakau rakyat diantaranya adalah penyediaan benih bermutu [4]. Pada umumnya, petani tembakau mendapat benih dari tanaman tembakau itu sendiri dan disimpan pada tempat yang kurang memenuhi syarat dengan kelembaban ruangan yang tinggi saat musim hujan. Hal ini menyebabkan rendahnya mutu benih yang dimiliki oleh petani. Penggunaan benih dengan daya berkecambah yang rendah akan meningkatkan biaya penyulaman dan harga benih serta pertumbuhan tanaman tidak merata sehingga produksi tidak optimal dan mutunya rendah [5]. Benih tembakau dikatakan memenuhi syarat standar mutu jika memiliki daya berkecambah lebih dari $80 \%$ [6].

Upaya mendapatkan varietas unggul baru dalam pemuliaan tanaman dapat dilakukan melalui introduksi, hibridisasi, induksi mutasi dan rekayasa genetika [7]. Diantara cara-cara tersebut mutasi merupakan salah satu cara yang dipandang paling murah dan cepat dalam upaya peningkatan keanekaragaman genetik tanaman. Induksi mutasi dapat dilakukan dengan menggunakan mutagen fisik atau kimiawi. Mutagen fisik yang sering digunakan adalah ionisasi sinar alpha, beta, gamma, fast neutron, elektron beam dan ion beam, sedangkan mutagen kimia adalah sulphur mustard, Colchisine, EMS dan DES [8]. EMS (Ethyl Methane Sulphonate) paling banyak digunakan karena sering menghasilkan mutan yang bermanfaat dan tidak bersifat mutagenik setelah terhidrolisis [9].

Beberapa penelitian melaporkan EMS menghasilkan peningkatan keanekaragaman dan menghasilkan mutan, misalnya dihasilkan mutan pisang yang resisten terhadap virus [10]. Mutagen EMS juga menyebabkan peningkatan keragaman varian dari abaka / pisang manila (Musa textilis) dan berhasil mendapatkan mutan yang tahan terhadap penyakit layu Fusarium [11] [12]. Penggunaan mutagen kimia EMS juga berpengaruh terhadap perkecambahan benih tanaman. Hasil penelitian [13] menunjukkan bahwa pada konsentrasi $0,5 \%$ dengan lama perendaman selama 6 jam memiliki efek menurunkan perkecambahan benih. Demikian pula pada penelitian yang dilakukan oleh [14] yang menunjukkan bahwa terjadi penurunan persentase perkecambahan pada benih padi seiring dengan meningkatnya konsentrasi EMS.

Beberapa penelitian mengenai penggunaan EMS dalam pemuliaan tanaman melatarbelakangi penelitian tentang pengaruh konsentrasi mutagen EMS terhadap daya berkecambah benih tanaman tembakau. Tujuan dari penelitian ini adalah untuk mengetahui pengaruh perbedaan konsentrasi EMS terhadap daya berkecambah benih tanaman tembakau dan berapakah konsentrasi yang berpengaruh terhadap daya berkecambah benih tanaman tembakau. Penelitian ini diharapkan mampu memberikan informasi mengenai pengaruh konsentrasi EMS terhadap daya berkecambah benih tanaman 
tembakau, yang diharapkan dapat mendukung produktivitas tembakau.

\section{METODOLOGI}

\section{A. Waktu dan tempat}

Penelitian ini dilakukan pada bulan Desember 2016 hingga bulan Maret 2017 di greenhouse dan Laboratorium Biosains dan Teknologi Tumbuhan Jurusan Biologi, Fakultas Matemtika dan Ilmu Pengetahuan Alam, Institut Teknologi Sepuluh Nopember.

\section{B. Alat dan bahan}

Alat yang digunakan pada penelitian ini yaitu gelas arloji, gelas ukur, gelas beker, pipet volume, bulb, corong gelas, cawan Petri, kaca pengaduk, kertas saring, neraca analitik, dan pot tray. Sedangkan bahan yang digunakan pada penelitian ini yaitu benih tanaman tembakau varietas Marakot, aquadest, EMS (Ethyl Methane Sulphonate) 100\%, buffer fosfat pH 7, tanah, pupuk NPK, dan fungisida.

\section{Cara kerja}

\section{1) Pembuatan larutan EMS (Ethyl Methane Sulphonate)}

Dibuat larutan stok EMS $10 \%$ terlebih dahulu. Disiapkan EMS konsentrasi $100 \%$ sebanyak $2 \mathrm{ml}$ lalu diencerkan dengan cara ditambah larutan buffer fosfat $\mathrm{pH} 7$ hingga volumenya menjadi $20 \mathrm{ml}$. Kemudian larutan diencerkan menjadi $0,1 \%$, $0,5 \%, 1 \%$, dan $1,5 \%$ dengan mengambil larutan stok EMS $10 \%$ sebanyak $0,2 \mathrm{ml}, 1 \mathrm{ml}, 2 \mathrm{ml}$, dan $3 \mathrm{ml}$ lalu masingmasing ditambah larutan buffer fosfat $\mathrm{pH} 7$ hingga volumenya menjadi $20 \mathrm{ml}$.

\section{2) Perendaman benih tembakau dengan EMS (Ethyl Methane Sulphonate)}

Benih tembakau disiapkan sebanyak $\pm 0,15$ gram, lalu direndam ke dalam $100 \mathrm{ml}$ aquadest di dalam gelas beker pada suhu ruangan selama $24 \mathrm{jam}$. Benih yang telah direndam dikeringkan diatas kertas saring. Digunakan 0,01 gram (120 biji) benih tembakau untuk setiap perlakuan perendaman dengan 3 kali ulangan. Benih yang digunakan untuk kontrol hanya direndam dengan aquadest. Sedangkan pada perlakuan menggunakan EMS, benih direndam dalam $20 \mathrm{ml}$ EMS konsentrasi $0,1 \%, 0,5 \%, 1 \%$, dan $1,5 \%$ selama 6 jam. Benih yang telah direndam selama 6 jam kemudian dibilas dengan air untuk menghilangkan sisa mutagen.

\section{3) Pengujian daya kecambah benih}

Pengujian dilakukan di dalam greenhouse dengan media tanam berupa tanah. Benih kontrol dan benih yang telah diberi perlakuan perendaman EMS ditanam pada pada pot tray yang telah diisi dengan media tanah. Dilakukan penyiraman sebanyak dua kali sehari yaitu pada pagi dan sore hari. Parameter daya berkecambah dihitung menurut rumus sebagai berikut :

$$
D K=\frac{J K}{J C} \times 100 \%
$$
DK: Daya kecambah (\%)
JK : Jumlah benih yang berkecambah
JC : Jumlah benih yang diujikan

\section{4) Rancangan penelitian dan analisa data}

Rancangan yang digunakan adalah rancangan acak lengkap (RAL) dengan satu faktor yaitu perbedaan konsentrasi EMS. Data yang diperoleh kemudian dianalisis menggunakan ANOVA One Way untuk mengetahui pengaruh konsentrasi mutagen EMS terhadap daya berkecambah benih tembakau yang dibandingkan dengan data kontrol. Kemudian dilakukan uji lanjutan Tukey apabila terdapat pengaruh perlakuan terhadap parameter yang diujikan.

\section{HASIL DAN PEMBAHASAN}

Hasil analisis statistik terhadap uji daya kecambah benih tembakau varietas Marakot dapat dilihat pada tabel berikut

Tabel 1.

Hasil rata-rata uji daya kecambah benih tembakau var. Marakot (0-21 hari pengamatan)

\begin{tabular}{cc}
\hline Perlakuan & Daya Kecambah (\%) \\
Kontrol & $78,89 \mathrm{a}$ \\
\hline $0,1 \%$ & $81,67 \mathrm{a}$ \\
$0,5 \%$ & $62,78 \mathrm{a}$ \\
$1 \%$ & $31,11 \mathrm{~b}$ \\
$1,5 \%$ & $6,67 \mathrm{~b}$ \\
\hline \hline
\end{tabular}

Keterangan: angka-angka yang diikuti huruf yang berbeda pada kolom yang sama menunjukkan beda nyata berdasarkan uji Tukey $5 \%$.

Berdasarkan tabel data tersebut, uji statistik ANOVA menunjukkan bahwa konsentrasi EMS berpengaruh nyata terhadap daya kecambah (DK), yaitu pada konsentrasi $1 \%$ dan $1,5 \%$.

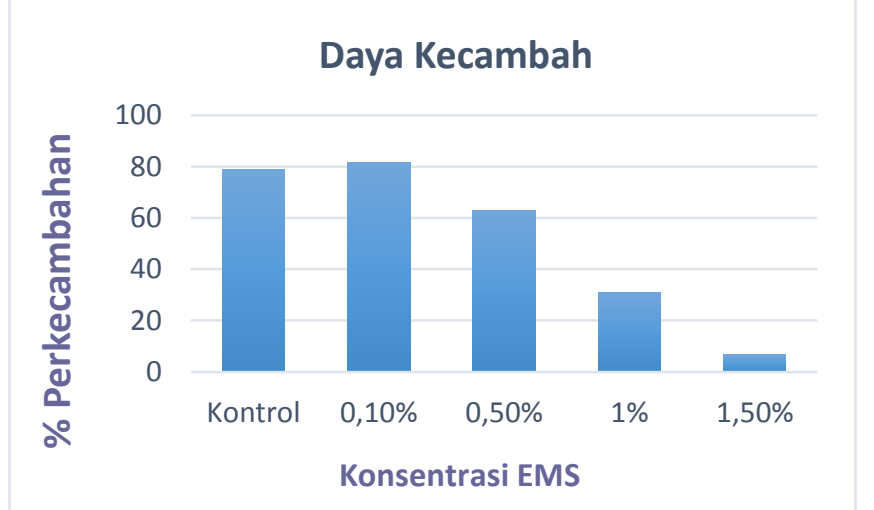

Gambar.1. Grafik pengaruh konsentrasi EMS terhadap daya kecambah benih tembakau var. Marakot (0-21 hari pengamatan).

Penurunan daya kecambah terjadi seiring dengan besarnya konsentrasi EMS, yang ditunjukkan pada grafik (Gambar 4.1). Daya kecambah paling rendah terdapat pada benih yang diberi perlakuan EMS dengan konsentrasi 1,5\%, yaitu sebesar $6,67 \%$. Hasil penelitian yang telah dilakukan sesuai dengan beberapa penelitian sebelumnya, yang menunjukkan bahwa efek penghambatan akan bertambah seiring dengan semakin tingginya konsentrasi EMS yang diberikan, dalam hal ini yaitu daya berkecambah benih. Pada penelitian yang dilakukan oleh [16] terhadap tanaman tembakau yang diberi perlakuan EMS dengan konsentrasi $0,1 \%, 0,3 \%$, dan $0,5 \%$ selama 12 jam 
menunjukkan daya kecambah paling rendah pada konsentrasi EMS tertinggi $(0,5 \%)$. Hasil serupa juga ditunjukkan pada jarak pagar (Jatropha curcas) [17] dan padi [14].

EMS masuk ke dalam benih ketika perlakuan perendaman, setelah benih mengalami proses imbibisi ketika benih direndam terlebih dahulu ke dalam aquadest. Imbibisi akan menyebabkan kulit biji menjadi lunak dan retak, sehingga EMS dapat masuk ke dalam benih tembakau. Masuknya EMS ke dalam benih akan menyebabkan mutasi titik pada DNA sel embrio yang ada di dalam benih dan akan menyebabkan perubahan susunan asam amino. Sintesis hormon dan enzim yang terganggu oleh EMS menyebabkan terhambatnya metabolisme pada benih [18]. Demikian juga dengan [19], yang menyatakan bahwa tingginya konsentrasi EMS dapat merusak promotor pertumbuhan, meningkatkan penghambat pertumbuhan dan metabolisme benih, dan menyebabkan berbagai penyimpangan kromosom. Hal ini ditunjukkan pada tabel hasil penelitian (Tabel 4), bahwa terhambatnya metabolisme pada benih berdampak pada daya kecambah benih yang rendah, yaitu pada benih yang diberi perlakuan mutagen kimia EMS dengan konsentrasi paling tinggi $(1,5 \%)$.

Efek EMS dalam menurunkan perkecambahan bisa dihubungkan dengan beda potensial air. Perbedaan potensial air di dalam sel dan di luar sel dapat menghambat perkecambahan benih karena adanya hambatan penyerapan air. Semakin besar konsentrasi partikel atau zat, makin rendah nilai potensial air. Meningkatnya potensial osmotik, EMS akan menurunkan potensial air sehingga akan menyulitkan benih mendapatkan air [20]. Konsentrasi EMS yang lebih tinggi dapat menurunkan potensial air di luar benih dan oleh karena itu benih tidak dapat melakukan imbibisi air yang cukup untuk perkecambahan [21].

Meskipun perkecambahan benih terhambat karena adanya EMS, tetapi kecambah tembakau masih dapat tumbuh pada semua konsentrasi perlakuan EMS. Hal ini diduga disebabkan karena adanya kemampuan benih untuk mengembangkan toleransi terhadap efek penghambatan mutagen dan benih tersebut telah meningkatkan kondisi fisiologis pada saat berlangsungnya proses perkecambahan, sehingga benih yang diberi perlakuan mutagen dapat mengalami perkecambahan walaupun lambat [22]. EMS merupakan senyawa yang beracun, sehingga menghambat pertumbuhan, tetapi akhirnya benih dapat beradaptasi dan mampu muncul ke permukaan tanah [23].

Selain efek penghambatan, EMS juga menunjukkan efek menstimulasi pertumbuhan benih. Pada perlakuan EMS dengan konsentrasi rendah $(0,1 \%)$, daya kecambah benih lebih tinggi dibandingkan dengan kontrol dan perlakuan EMS lainnya, yaitu $81,67 \%$ (Tabel 4). Menurut [24], pemberian mutagen EMS dengan konsentrasi yang rendah dapat menjadikan benih tetap viabel, akan tetapi variasi genetik yang dihasilkan mungkin rendah karena sedikitnya mutagen yang masuk ke dalam benih. Sebaliknya, pemberian EMS dengan konsentrasi yang tinggi dapat memunculkan lebih banyak variasi genetik karena banyaknya mutagen yang masuk ke dalam benih, meskipun benih tersebut memiliki daya berkecambah yang rendah dan tingkat kematian yang tinggi. [25] menyatakan bahwa semakin tinggi konsentrasi EMS menyebabkan semakin banyak EMS yang terserap sehingga toksisitas EMS semakin bertambah.

\section{KESIMPULAN}

Berdasarkan penelitian yang telah dilakukan, dapat disimpulkan bahwa:

1. Perlakuan mutagen EMS dengan konsentrasi yang berbeda terhadap benih tanaman tembakau memberikan pengaruh nyata terhadap daya kecambah benih.

2. Perlakuan mutagen EMS dengan konsentrasi $1 \%$ dan $1,5 \%$ memberikan pengaruh menurunkan daya perkecambahan benih tembakau.

\section{LAMPIRAN}

Tabel 2

Hasil uji daya kecambah benih

\begin{tabular}{ccc}
\hline \multicolumn{3}{c}{ Hasil uji daya kecambah benih } \\
\hline \multirow{2}{*}{ Perlakuan } & Ulangan & $\begin{array}{c}\text { Daya } \\
\text { berkecambah (\%) }\end{array}$ \\
\hline \multirow{3}{*}{ Kontrol } & 1 & 79,17 \\
& 2 & 80,83 \\
\multirow{2}{*}{$0,1 \%$} & 3 & 76,67 \\
& 1 & 100,00 \\
$0,5 \%$ & 2 & 85,00 \\
& 3 & 60,00 \\
& 1 & 60,00 \\
$1,0 \%$ & 2 & 75,83 \\
& 3 & 52,50 \\
& 1 & 40,83 \\
$1,5 \%$ & 2 & 29,17 \\
& 3 & 23,33 \\
& 1 & 5,00 \\
& 2 & 5,83 \\
\hline \hline
\end{tabular}

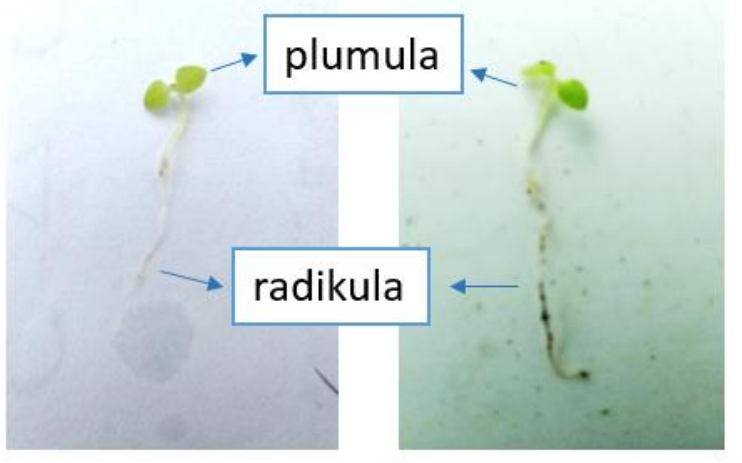

Gambar 2. Gambar Kecambah Tembakau Normal (umur 1 minggu)

\section{DAFTAR PUSTAKA}

[1] R. Hanadyo., T. Hadiastono., dan M. Martosudiro. Pengaruh Pemberian Pupuk Daun Cair Terhadap Intensitas Serangan Tobacco Mosaic Virus (TMV), Pertumbuhan, dan Produksi Tanaman Tembakau (Nicotiana tabacum L.). Jurnal HPT. 1(2): 28-36 (2013).

[2] E. A. Putri., A. Suwandari., dan J. A. Ridjal. Analisis Pendapatan dan Efisiensi Biaya Usahatani Tembakau Maesan 2 di Kabupaten Bondowoso. JSEP. 8(1): 64-69 (2015).

[3] M. K. Lesilolo., J. Patty dan N. Tetty. Penggunaan Desikan Abu dan Lama Simpan Terhadap Kualitas Benih Jagung (Zea mays L.) pada Penyimpanan Ruang Terbuka. Jurnal Agrologia. 1(1): 51-59 (2012).

[4] A. H. Rachman. Status Pertembakauan Nasional, Prosiding Lokakarya Nasional Agribisnis Tembakau. Pusat Penelitian dan 
Pengembangan Perkebunan. Badan Penelitian dan Pengembangan Pertanian, Surabaya (2007).

[5] M. Hasanah. Peran Mutu Fisiologik Benih dan Pengembangan Benih Tanaman Industri. Jurnal Litbang Pertanian. 21(2): 8 (2002).

[6] SNI. Standar Nasional Indonesia: Benih Tembakau Kelas Benih Dasar dan Benih Sebar. SNI. 01-7161-2006. ICS 27-180. Standar Nasional Indonesia. Badan Standarisasi Nasional (2006).

[7] L.Sari., A. Purwito., D. Sopandie., R. Purmaningsih., dan Enny Sudarmonowati. Pengaruh Irradiasi Sinar Gamma pada Pertumbuhan Kalus dan Tunas Tanaman Gandum (Triticum aestivum L.). Jurnal Ilmu Pertanian. 1(1) : 44-50 (2015).

[8] L.V. Crowder. Genetika Tumbuhan. Terjemahan Kusdiarti, L., Sutarso (ed). Gadjah Mada University Press, Yogyakarta (1993).

[9] A.M. Van Harten. Mutation Breeding: Theory and Practical Application. Cambridge University Press, New York. (1998).

[10] M. Imelda., Deswina, P., Hartati, S., Estiati, A., and Atmowijoyo, S. Chemical Mutation by Ethyl Methane Sulfonate (EMS) for Bunchy Top. Virus Resistence in Banana. Annales Bogorienses. 38(3): 205-211 (2000).

[11] R.D. Purwati., Budi, U., dan Sudarsono, S. Penggunaan Asam Fusarat dalam Seleksi in vitro untuk Resistensi terhadap Fusarium oxysporum. Jurnal Littri. 7(2): 80-91 (2007).

[12] R.D. Purwati., Sudjindro, K.E., dan Sudarsono, S. Keragaman Genetika Varian Abaka yang Diinduksi dengan Ethyl Methane Sulphonate (EMS). Jurnal Littri. 15(4): 152-161 (2008).

[13] N. Jabeen., and Mirza, B. Ethyl Methane Sulfonate Induces Morphological Mutations in Capsicum annuum. International Journal of Agriculture Biology. 6(2): 340-345 (2004).

[14] A.B. Talebi., A.B. Talebi., and Behzad Shahrokhifar. Ethyl Methane Sulphonate (EMS) Induced Mutagenesis in Malaysian Rice (cv. MR219) for Lethal Dose Determination. American Journal of Plant Sciences. 3: 1661-1665 (2012).

[15] H. Kuswanto. Dasar-Dasar Teknologi Produksi dan Sertifikasi Benih. Penerbit Andi, Yogyakarta (1996).

[16] S. Amarnath and A.B. Prasad. Induced Variability in Homozygous and Heterozygous Genotypes of Tobacco. Indian Journal of Genetics. 58(1): 69-77 (1998).

[17] D. Dhakshanamoorthy., R. Selvaraj., dan A. Chidambaram. Physical and Chemical Mutagenesis in Jatropha Curcas L. to Induce Variability in Seed Germination, Growth and Yield Traits. Journal of Plant Biology. 55(2): 113-125 (2012).

[18] J. Sambrook, and D.W. Russel. Molecular Cloning : A Laboratory Manual. Eds 3. New York : Cold Spring Harbor Laboratory Press (2001).

[19] S. Jayakumar., and Selvaraj R. Mutagenic Effectiveness and Efficiency of Gamma Rays and Ethyl Methane Sulphonate in Sunflower (Helianthus annus L.). Madras Jurnal Agriculture. 90(1): 574-576 (2003).

[20] A. R. Loveless. Prinsip Prinsip Biologi Tumbuhan Untuk Daerah Tropik. Jilid 1. Jakarta: PT. Gramedia Pustaka (1991).

[21] R. Singh., and Kole, C.R. Effect of Mutagenic Treatments with EMS on Germination and Some Seedling Parameters in Mungbean. Crop Research. 30(2): 236-240 (2005).

[22] F. Al-Qurainy., and S. Khan. Mutagenic Effects of Sodium Azide and its Application in Crop Improvement. World Applied Sciences Journal. 7(2): 220-226. (2009).

[23] N. K. Rustini., dan M. Pharmawati. Aksi Ethyl Methane Sulphonate terhadap Munculnya Bibit dan Pertumbuhan Cabai Rawit (Capsicum frutescens L.). Jurnal Bioslogos. 4(1):1-8 (2013).

[24] D. K. Lee., Y. S. Kim., and J. K. Kim. Determination of The Optimal Condition for Ethylmethane Sulfonate-Mediated Mutagenesis in Korean Commercial Rice, Japonica Cv. Dongjin. Applied Biological Chemistry (2017).

[25] Priyono dan A.W Susilo. Respon Regenerasi In vitro Eksplant Sisik Mikro Kerk Lily (Lilium longiflorum) terhadap Ethyl Methane Sulfonate (EMS). Jurnal Ilmu Dasar. 3(2): $74-79$ (2002). 